\title{
The Influence of Surfactant/Co-Surfactant Hydrophilic-Lipophilic Balance on the Formation of Limonene-Based Microemulsion as Vitamin C Carrier (Pengaruh Keseimbangan Hidrofilik-Lipofilik Surfaktan/Ko-Surfaktan terhadap Pembentukan Mikroemulsi Berasaskan Limonena sebagai Pembawa Vitamin C)
}

\author{
RAMLI, S.*,CHYi, K.T.,ZAinUdDin, N., MOKHTAR, W.N.A.W.\& ABdUl RAHMAN, I.
}

\begin{abstract}
This research was conducted to produce a limonene-based microemulsion system as vitamin C carrier. The microemulsion was produced using limonene as the oil phase, tween 20 and tween80 as surfactants while propylene glycol, polyethylene glycol 400 and glycerol as co-surfactants. Pseudo-ternary phase diagrams were constructed to determine the microemulsion area by using the water titration method at $25^{\circ} \mathrm{C}$. The effect of hydrophilic-lipophilic balance (HLB) value of the mixture of S/CoS on the formation of limonene-based microemulsion was studied.The HLB value calculated for the mixture of tween20/propylene glycol in the different ratio was between 10.1 and 13.4. From the experiment, the preparation of limonene-based microemulsion system with tween20/propylene glycol was able to provide large and high stability of microemulsion region on ternary phase diagram (23.6\%) while higher HLB value resulted in larger microemulsion area in ternary phase diagrams. The sole formulation with propylene glycol was further selected to carry out the physicochemical characterization of system's stability, particle size and electrical conductivity. All microemulsion systems showed good stability for four weeks at temperature of 4,25 and $40^{\circ} \mathrm{C}$ without any phase change and separation. Particle size characterization results elucidated that all microemulsion systems consisted particle size between 20 and $100 \mathrm{~nm}$. The study of electrical conductivity showed that water-in-oil microemulsion was formed from 5-45\% wt. of water whereas bicontinuous microemulsion was formed from 50-90\% wt. of water content. Overall, the result showed that microemulsion tween20/propylene glycol/limonene/water was potential as a carrier system of vitamin $C$.
\end{abstract}

Keywords: HLB; limonene; microemulsion; propylene glycol; tween 20

\section{ABSTRAK}

Kajian ini dijalankan untuk menghasilkan satu sistem mikroemulsi berasaskan limonena sebagai pembawa vitamin C. Mikroemulsi dihasilkan dengan menggunakan limonena sebagai fasa minyak, campuran tween20 dan tween80 sebagai surfaktan, manakala propilena glikol, polietilena glikol 400 dan gliserol bertindak sebagai ko-surfaktan. Rajah fasa pseudo-ternari dibina bagi menentukan keluasan rantau pembentukan mikroemulsi yang menggunakan kaedah penitratan air pada suhu $25^{\circ} \mathrm{C}$. Kesan nilai keseimbangan hidrofilik-lipofilik (HLB) bagi campuran S/KoS terhadap pembentukan mikroemulsi berasaskan limonena turut dikaji. Nilai HLB bagi campuran tween20/propilene glikol dalam pelbagai nisbah adalah antara 10.1 dan 13.4. Penyediaan sistem mikroemulsi berasaskan limonena dengan tween20/propilena glikol berupaya memberikan rantau mikroemulsi yang luas pada gambar rajah fasa ternari (23.6\%). Berdasarkan kajian ini, nilai HLB yang tinggi telah memberikan rantau mikroemulsi yang lebih luas pada gambar rajah fasa ternari. Formulasi yang terdiri daripada propilena glikol dipilih untuk pencirian fizikokimia yang melibatkan kestabilan sistem, saiz partikel dan kekonduksian elektrik. Perbandingan sifat fizikokimia dilakukan bagi sistem mikroemulsi yang mengandungi vitamin C serta sistem asas tanpa penambahan vitamin C. Kesemua sistem mikroemulsi yang dikaji menunjukkan kestabilan yang tinggi selama empat minggu pada suhu 4, 25 dan $40^{\circ} \mathrm{C}$ tanpa sebarang perubahan dan pemisahan fasa. Pencirian saiz partikel menunjukkan sistem mikroemulsi mempunyai saiz partikel antara 20 dan $100 \mathrm{~nm}$. Ujian kekonduksian elektrik pula menunjukkan mikroemulsi jenis air-dalam-minyak $(\mathrm{a} / \mathrm{m})$ terbentuk bagi peratusan air 5-45\% bt. manakala peratusan air antara 50-90\% bt. membentuk mikroemulsi dwiselanjar. Secara keseluruhan, sistem mikroemulsi tween20/propilena glikol/limonena/air berpotensi sebagai sistem pembawa vitamin $C$.

Kata kunci: HLB; limonena; mikroemulsi; propilena glikol; tween20

\section{INTRODUCTION}

Many approaches have been used as well as many topical formulations developed in order to treat skin problems such as eczema, psoriasis, acne and wound healing (Prausnitz \& Langer 2008). Consumers nowadays are more concerned and focused on their skin health and appearance, therefore, the demands for having suitable and good products for skin care and treatment are gaining more attention. Thus, cosmetic manufacturers struggle to find ways to produce an effective product that matches all the needs of 
consumers. In the cosmeceuticals field, one should consider all the important factors in the development of cosmetic products such as age, skin type, sex, skin disease as well as environmental factors such as pollution (Alexander et al. 2012; Khalid et al. 2018; Shah et al. 1992).

Research and development in cosmetic products need to be continuously carried out in order to ensure the effectiveness and effication of the formulations to deliver the active ingredients, particularly for targeted cases such as acne treatment (Shah et al. 1992). Huge number of weaknesses regarding cosmetic products were reported; for example, the instability of active ingredients in the formulations and high sensitivity towards $\mathrm{pH}$, temperature, light and oxidation process. The ineffectiveness of the active ingredients and lead to side effects such as irritation and allergy to the consumers caused by the degradation of cosmetic products (Chin 2013; Shaninuzzaman et al. 2016). All these forethoughts have been a driving force for the development of new technology for manufacturers of formulations that can prevent the degradation of active ingredients as well as improve their delivery in a sustained and controlled manner.

Along with that, the development of microemulsion in cosmetic and drug delivery has also gained much attention. The great properties of microemulsion as a carrier was due to its small particle sizes, thermodynamic stability and ease of preparation (Ismail et al. 2014; Rozman et al. 2009). This system also shows good tolerance towards storage temperature without aggregation and creaming that usually appear in emulsion and gel systems. As a carrier, microemulsion is able to deliver both hydrophilic and hydrophobic drugs due to their hydrophilic and hydrophobic structures. Research on the development of microemulsion as topical and transdermal drug delivery has also increased year by year due to the unique properties of the system itself (Lawrence \& Rees 2000).

Transdermal drug delivery has been considered as an alternative route that able to improve the problems faced by conventional drug delivery such as oral and parenteral (Rehman \& Zulfakar 2014; Rehman et al. 2014; Lopes 2014). It can avoid the degradation of active ingredients caused by stomach acidity, is less painful compared to the parenteral route and able to deliver drugs at a therapeutic level into the blood capillary without any side effect as well as control and prolong the delivery of drugs (Prausnitz \& Langer 2008).

The stability of microemulsion somehow is known to be affected by the HLB value of the surfactant and the oil/surfactant ratio (Mohd Nadzir et al. 2017). The HLB values are able to predict the action of a surfactant; for example, HLB $<10$ would be suitable for water-in-oil microemulsion, while HLB $>10$ would be suitable for oil-inwater microemulsion (Gadhave \& Waghmare 2014). The HLB range of 10-15 has been suggested for the formation of microemulsion that has high stability and smaller droplet diameter (Bachysky et al. 1997). In addition, the higher oil content can be good in order to dissolve more drugs in the microemulsion system, but it might affect the microemulsion stability and droplet size (Pouton 1985).
Limonene is suitable as oil phase and other than that, it is also able to act as a penetration enhancer for topical and transdermal systems (Alexander et al. 2012). Furthermore, limonene is an essential oil that had been reported to increase the penetration of drugs through the stratum corneum (Fanun 2010; Jadhav \& Sreenivas 2012; Liu et al.2011). Taking this into account, this research was conducted to develop the limonene-based microemulsions as the carrier of vitamin $\mathrm{C}$. The effects of surfactant and co-surfactant on the development and physicochemical properties of microemulsion were examined. Tween20 and tween 80 were used as surfactants, while propylene glycol (PG), polyethylene glycol 400 (PEG 400) and glycerol were functioned as co-surfactants. Pseudo-ternary phase diagram was constructed to determine the optimum ratio of surfactant/co-surfactant:oil (S/CoS:oil) and S/CoS (Km) as well as the influence of HLB value to the system.

\section{MATERIALS AND METHODS}

Ascorbic acid (vitamin C), D-limonene, polyoxylethylene sorbitan monolaurate (Tween20), polyoxylethylene sorbitan monooleate (Tween80) and polyethylene glycol 400 (PEG400) were purchased from Merck, Germany. Glycerol and sodium chloride were purchased from Systerm, Malaysia and propylene glycol was purchased from Sigma Aldrich, USA. All chemicals used were of analytical grade and used without further purification. Distilled water was used throughout the experiment.

\section{PREPARATION OF MICROEMULSIONS}

A pseudo-ternary phase diagram was constructed in order to determine the microemulsion region at any component percentage. The phase diagram was constructed using water titration method at ambient temperature $\left(25^{\circ} \mathrm{C}\right)$. Three ternary phase diagrams were constructed with the ratio of tween20:propylene glycol, $\mathrm{Km}$ at 1:1,2:1 and 3:1. In each ternary phase diagram, the ratios of the mixture of surfactant/co-surfactant used were 1:9, 2:8, 3:7, 4:6, 5:5, 6:4, 7:3, 8:2, 9:1 (Ramli et al. 2017, 2015; Zainuddin et al. 2017). Water was added dropwise into the mixture of oil, surfactant and co-surfactant and homogenised using a magnetic stirrer. The microemulsions were observed visually to determine if any phase separation, cloudiness, precipitation and coagulation occurred after $24 \mathrm{~h}$. The percentage of each component (water, oil, S/CoS) that was able to form microemulsion was plotted in the pseudoternary diagram (Chen et al. 2004; Ramli et al. 2017; Zainuddin et al. 2017).

\section{PHYSICAL CHARACTERIZATIONS OF MICROEMULSIONS}

The stability of microemulsions was investigated via any changes and phase separation at three different temperatures $\left(4,25\right.$ and $\left.40^{\circ} \mathrm{C}\right)$ (Gao et al. 1998). It was observed visually once every week for 4 weeks (Liu et al. 2011; Ramli et al. 2017; Zainuddin 2017). The average particle size and polydispersion systems were studied by 
using dynamic light scattering (DLS) at $25^{\circ} \mathrm{C}$ (Ramli et al. 2009). The electrical conductivity of the system was tested by using a conductometer and a solution of $0.01 \mathrm{M}$ $\mathrm{NaCl}$ was used as the source of electrolyte replacing water (Hathout et al. 2010). Determination of particle sizes and conductivity was repeated three times $(n=3)$.

\section{RESULTS AND DISCUSSION}

\section{CONSTRUCTION OF PSEUDO-TERNARY PHASE DIAGRAMS}

The effects of surfactant on the formation of limonenebased microemulsions were studied by using two different surfactants which were tween 80 and tween 20 . The screening of the formation of microemulsion at each $\mathrm{Km}$ showed that the mixture of tween 80/propylene glycol/ limonene/water was able to form microemulsion at $\mathrm{Km}=3: 1$ (Figure 1(a)) but unable to form stable microemulsion systems at $\mathrm{Km}=2: 1$ and $1: 1$. It also showed that the mixture of tween 80/propylene glycol and limonene could not form a stable microemulsion system when exceeding $30 \%$ wt. of water content. However, these systems were provided a stable microemulsion system at the ratio of $\mathrm{S} /$ CoS:oil from 9:1 to 5:5 for 5-15\% wt. of water content, but no microemulsion system was observed for the ratio of $\mathrm{S} / \mathrm{CoS}$ :oil from 4:6-1:9. It showed that for the ratio of S/CoS:oil (9:1), the microemulsion system was formed up to $15 \%$ wt. of water content; however, the addition of water content was only $5 \% \mathrm{wt}$. in order to form a stable microemulsion system at the ratio of 8:2-5:5.

Microemulsion consisting of tween20/propylene glycol and limonene (Figure 1(b)) resulted in a larger microemulsion region with $23.6 \%$ at the same ratio of S/CoS:oil compared to tween $80 /$ propylene glycol with only $8.2 \%$. The tween20/propylene and limonene based microemulsion was able to form a microemulsion system at the ratio of S/CoS:oil from 9:1-6:4 with an addition of $5-80 \%$ wt. of water content. This system also showed that the highest water content added ( $80 \% \mathrm{wt}$.) was able to form a microemulsion system at the ratio of S/CoS:oil, 9:1. The HLB values of tween 80 and tween20 were 15.0 and 16.7, respectively. The high emulsification ability of mixture tween20/propylene glycol (HLB=13.38) compared to the mixture of tween80/propylene glycol (HLB 12.1) was due to its higher HLB mixture of S/CoS which contributed to more effective packing in the oil/water interfacial layer and greater interfacial rigidity (Kale \& Deore 2017; Matsaridou et al. 2012; Sail et al. 2018).

Subsequently, the effects of different co-surfactants on the formation of tween20/limonene-based microemulsion were studied by using glycerol, polyethylene glycol 400 and propylene glycol at $\mathrm{Km}=1: 1,2: 1$ and $3: 1$ as shown in Figures 2, 3 and 4, respectively. The HLB values of each co-surfactant were 3.4, 11.6 and 3.8, respectively. The results showed that the addition of polyethylene glycol 400 formed the largest microemulsion region on the ternary phase diagram for all $\mathrm{Km}=1: 1,2: 1$ and 3:1 with 16.9, 28.1 and $30.2 \%$, respectively, compared to propylene glycol $(10.3,18.3$ and $23.6 \%$, respectively) and glycerol (2.2, 23.4 and $27.8 \%$, respectively). Table 1 shows the summary of HLB value calculated for the of S/CoS mix at each Km. Although the range of HLB of the S/CoS mix (10.1-15.4) was not too broad, the HLB values of the S/CoS mix could be considered as the main factor that affected the formation of the microemulsion system. Here, as the higher the S/ $\mathrm{CoS}$ mix HLB values, the bigger the microemulsion region plotted in the ternary phase diagram. This might be due to the higher emulsification ability of the mixture caused by higher HLB mixture of S/CoS that contributed to more effective packing in the oil/water interfacial layer and greater interfacial rigidity, hence increasing the potential of the formation of microemulsion system. As an addition, polyethylene glycol 400 has a low molecular weight and one of the short chain alcohol group that commonly used in the preparation of microemulsion. Its able to form a stable microemulsion system with minimum amount and showed high solubility effect on active ingredients (Basit et al. 1998; Cuit et al. 2009).

Further physicochemical characterizations were studied for the tween20/propylene glycol/limonene/water microemulsions at the ratios of S/CoS:oil, 9:1 and $\mathrm{Km}=3: 1$. The mixture of tween 20 and propylene glycol showed the
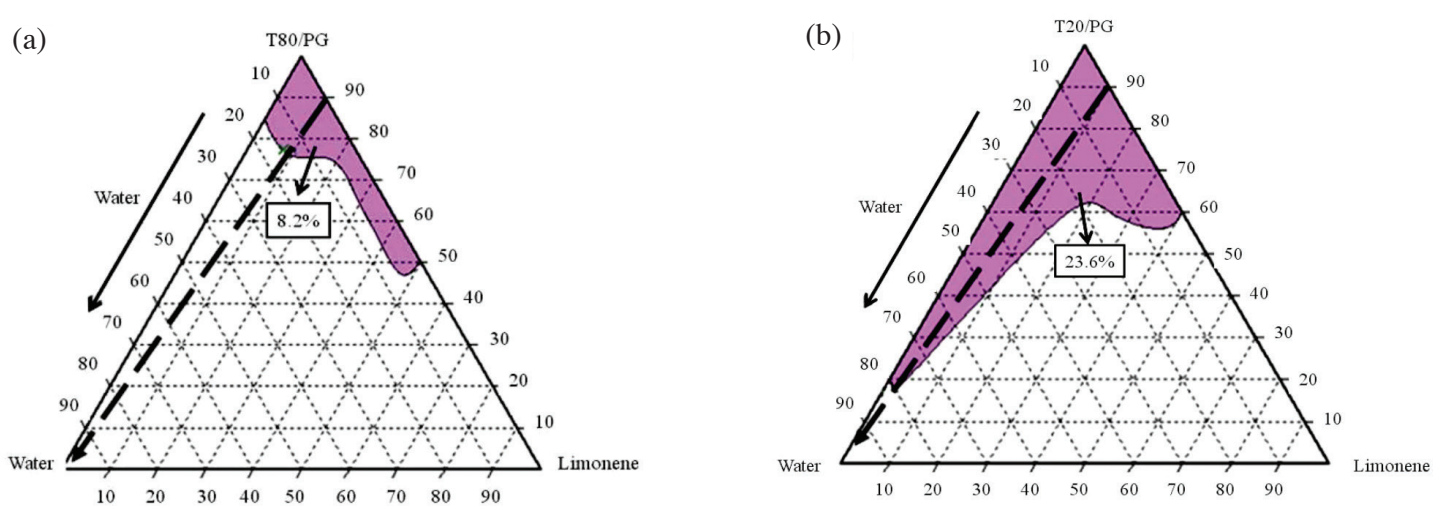

FIGURE 1. Pseudo-ternary phase diagrams of microemulsion (a) tween80/propylene glycol/limonene/water,

(b) tween20/propylene glycol/limonene/water at $\mathrm{Km}=3: 1$ 
(a)

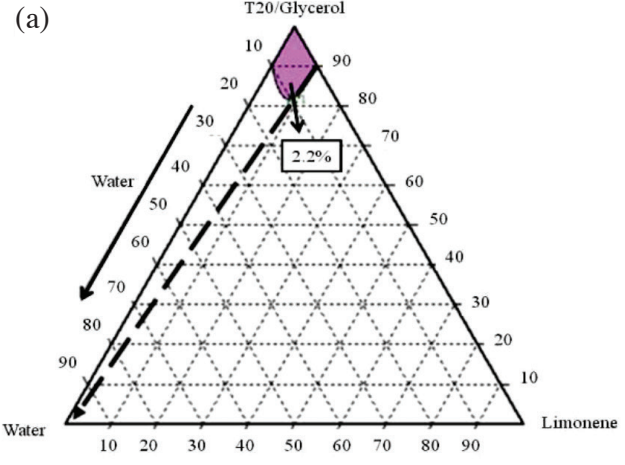

(b)

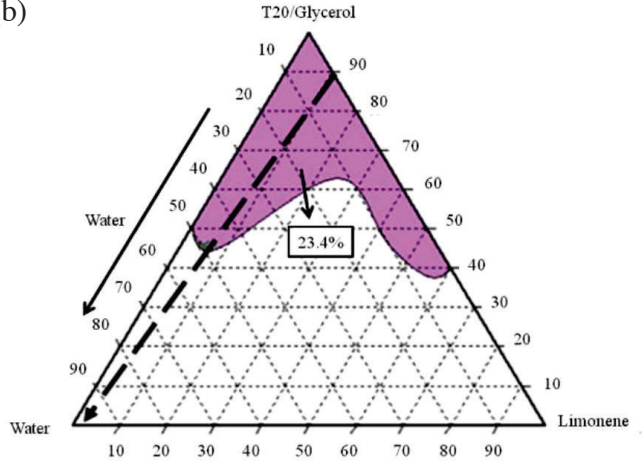

(c)

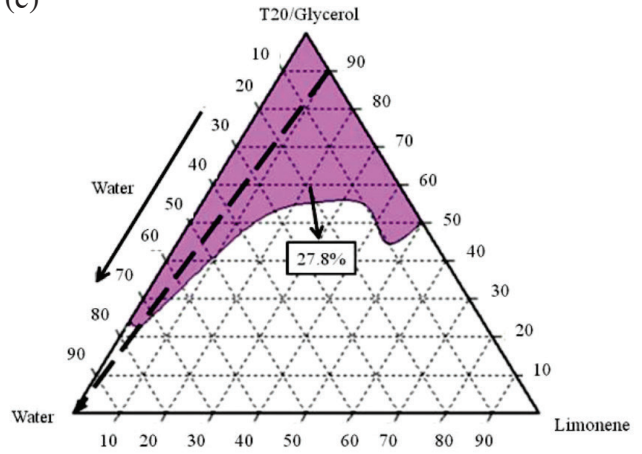

FIGURE 2. Pseudo-ternary phase diagrams of tween20/glycerol/limonene/water microemulsion at (a) $\mathrm{Km}=1: 1$, (b) $\mathrm{Km}=2: 1$, (c) $\mathrm{Km}=3: 1$
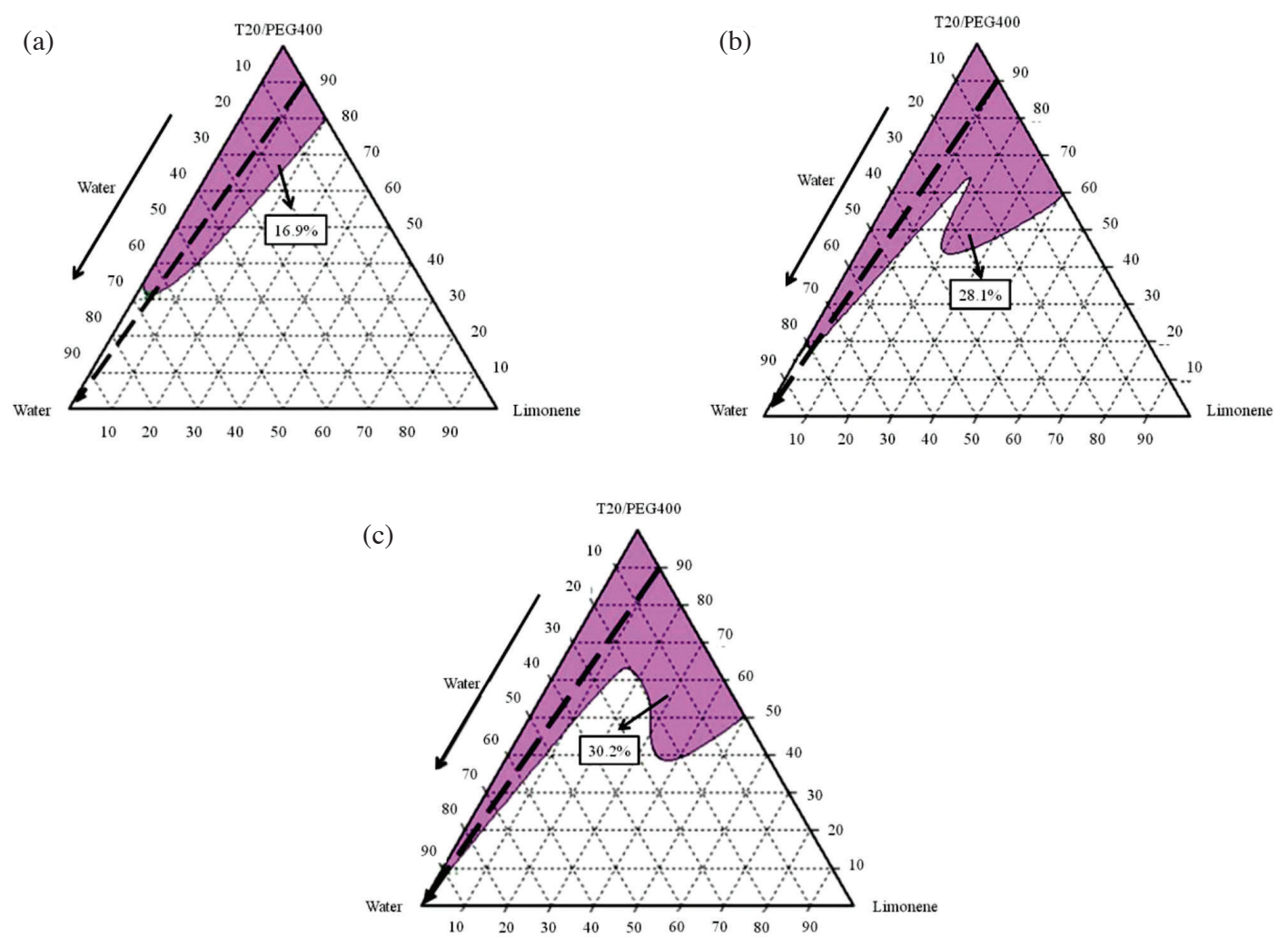

FIGURE 3. Pseudo-ternary phase diagrams of tween20/polyethylene glycol 400/limonene/water at (a) $\mathrm{Km}=1: 1$, (b) $\mathrm{Km}=2: 1$, (c) $\mathrm{Km}=3: 1$ 
(a)

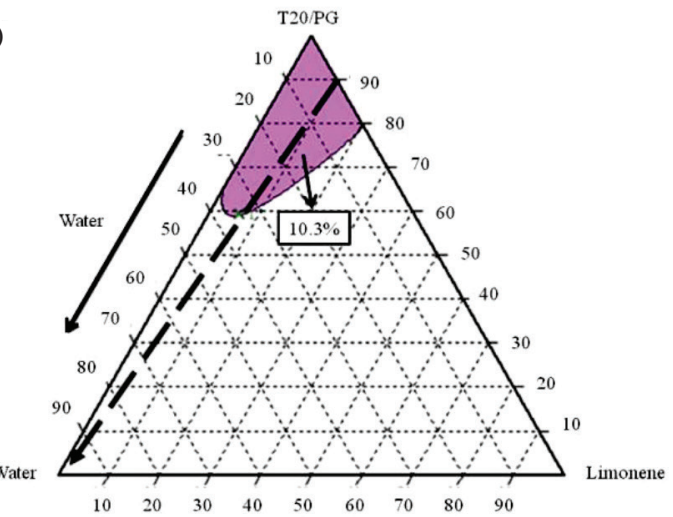

(b)

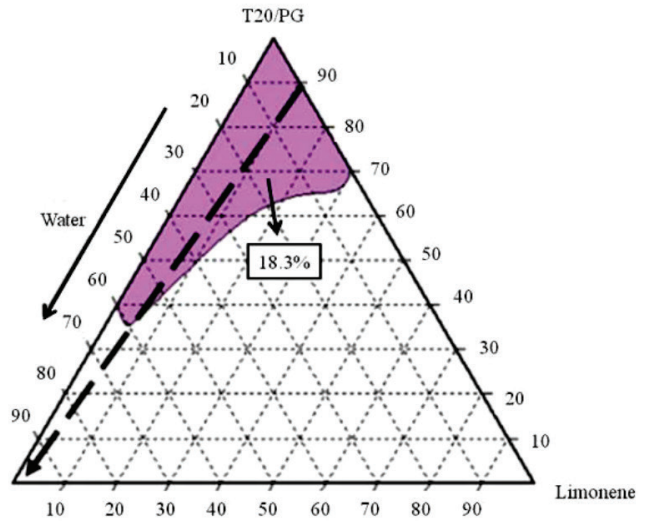

(c)

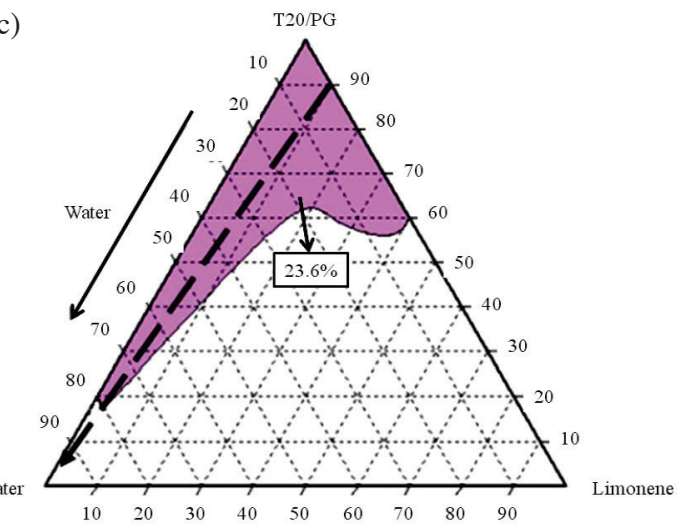

FIGURE 4. Pseudo-ternary phase diagrams of tween20/propylene glycol/limonene/ water at (a) $\mathrm{Km}=1: 1$, (b) $\mathrm{Km}=2: 1$, (c) $\mathrm{Km}=3: 1$

TABLE 1. The HLB values of mix S/CoS at each $\mathrm{Km}$ for tween20/limonene-based microemulsions

\begin{tabular}{lccc}
\hline \multirow{2}{*}{ Mix S/CoS } & \multicolumn{3}{c}{ HLB value } \\
\cline { 2 - 4 } & $\mathrm{Km}=1: 1$ & $\mathrm{Km}=2: 1$ & $\mathrm{Km}=3: 1$ \\
\hline Tween20/glycerol & 10.25 & 12.38 & 13.48 \\
Tween20/polyethylene glycol & 14.15 & 14.96 & 15.43 \\
Tween20/propylene glycol & 10.05 & 12.25 & 13.38 \\
\hline
\end{tabular}

desirable HLB value for the formation of limonene-based microemulsions.

\section{STABILITY OF MICROEMULSIONS}

The stability of tween20/limonene/propylene glycol/ water at $\mathrm{Km}=3: 1$ was investigated for the basic system (without vitamin C) and system with vitamin $\mathrm{C}$ for four weeks at the temperatures of 4,25 dan $40^{\circ} \mathrm{C}$. The samples were observed every week for any phase separation, cloudiness, precipitation or coagulation. For the basic system, it was only observed that the system turned cloudy at high water content which were $50-80 \%$ wt. and at very low temperature, $4^{\circ} \mathrm{C}$. This may be due to instability of the mixture and coagulation of internal phase at lower temperature (Zainuddin et al. 2017). As a comparison, the systems up to $40 \%$ of water content showed high stability and remained clear for all stored temperatures. Addition of vitamin $\mathrm{C}$ into the tween20/limonene/propylene glycol/water microemulsion showed the same physical stability as the basic system. This also showed that the addition of vitamin $\mathrm{C}$ did not affect the stability of basic microemulsion system. Figure 5 shows the stability of basic microemulsions and vitamin $\mathrm{C}$-loaded microemulsion in storage at the temperatures of 4,25 dan $40^{\circ} \mathrm{C}$.

\section{PARTICLE SIZE}

Average particle size is another important characterizations for the determination of the stability and particle size distribution of microemulsion systems (Chen et al. 2004). The particle sizes of both basic and with the addition vitamin C systems of tween20/limonene/propylene glycol/ water at $\mathrm{Km}=3: 1$ were studied for 20, 40 dan $60 \%$ wt. of water content as shown in Table 2. Overall, sample with $20 \%$ wt. of water content resulted in the highest average particle size compared to 40 and $60 \%$ wt. of water content. This might be due to the excess surfactant left in the oil 

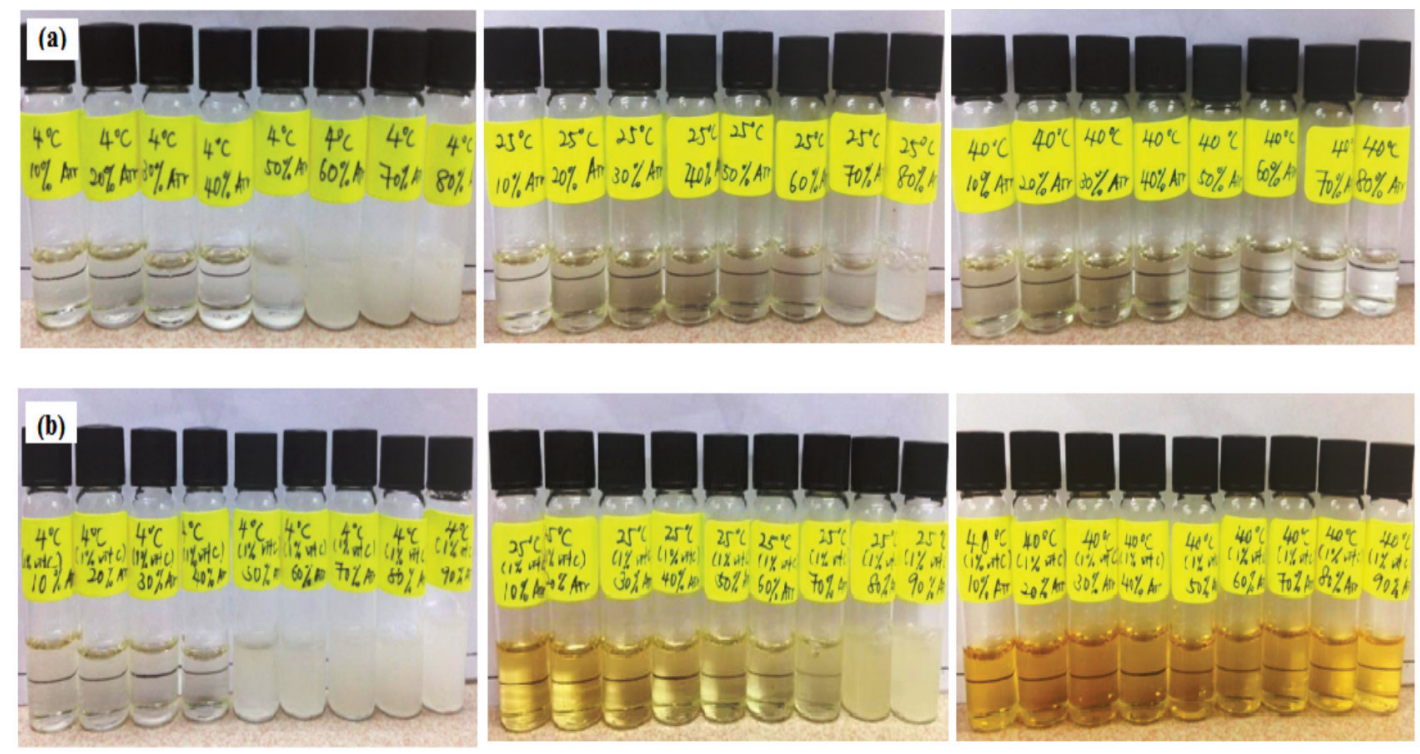

FIGURE 5. Microemulsions stability at $4^{\circ} \mathrm{C}, 25^{\circ} \mathrm{C}$ and $40^{\circ} \mathrm{C}$ for (a) basic microemulsions, (b) vitamin C-loaded microemulsions

TABLE 2. The average particle sizes of basic system and with an addition of vitamin C

\begin{tabular}{ccc}
\hline \multirow{2}{*}{ Water content $(\%)$} & \multicolumn{2}{c}{ Average particle size $(\mathrm{nm})$} \\
\cline { 2 - 3 } & Basic microemulsion & Vitamin C-loaded microemulsion \\
\hline 20 & $82.97 \pm 3.94$ & $142.20 \pm 7.82$ \\
40 & $61.79 \pm 9.12$ & $132.53 \pm 5.18$ \\
60 & $69.43 \pm 2.72$ & $55.65 \pm 1.44$ \\
\hline
\end{tabular}

phase that formed a surfactant bilayer instead of interfacial layer of oil-water and led to larger average particle sizes (Kogan et al. 2007).

All basic systems recorded average particle sizes in the range of 20-100 $\mathrm{nm}$. However, the addition of vitamin C has increased the average particle size of the basic system and only the system with $60 \%$ wt. of water content resulted in $<100 \mathrm{~nm}$. Even though the addition of vitamin $\mathrm{C}$ at 20 and $40 \%$ wt. of water content resulted in $>100 \mathrm{~nm}$ particle sizes, the systems remained stable and no phase separation was observed throughout the 4 weeks. The large average particle sizes for vitamin C-loaded microemulsion systems at 20 and $40 \%$ wt. of water content may be due to the water-soluble property of vitamin $\mathrm{C}$. This can cause the vitamin $\mathrm{C}$ to be present in the core particle of water-in-oil system and increase the droplet diameter, hence resulting in larger particle sizes compared to the basic system. Based on the average particle size of both systems, the higher water content resulted in the smallest average particle size. Besides that, the addition of vitamin $\mathrm{C}$ also resulted in the smallest particles compared to the basic system at $60 \%$ wt. of water content. This might be due to the intercalation of vitamin $\mathrm{C}$ at the external phase of microemulsion in a bicontinuous phase (Jadhav \& Sreenivas 2012; Ozturk et al. 2015). Smaller average particle size is one of the key points in microemulsion studies since it can improve the systems' stability to prevent any precipitation and flocculation (Herrera et al. 2003).

\section{ELECTRICAL CONDUCTIVITY}

The electrical conductivity was carried out to differentiate between the water-in-oil (w/o), bicontinuous or oil-inwater $(\mathrm{o} / \mathrm{w})$ microemulsion. The solution of sodium chloride $(\mathrm{NaCl})$ as the source of electrolyte was necessary instead of distilled water when the microemulsion system was prepared with a non-ionic surfactant (Hathout et al. 2010; Jadhav \& Sreenivas 2012; Ramli et al. 2015). Figure 6 shows the conductivity of tween20/limonene/propylene glycol/water at $\mathrm{Km}=3: 1$.

Electrical conductivity of both systems was increased as the water content was increased. Lower conductivity value was observed at the water content of $<50 \%$ wt. and started to increase drastically at $50 \%$ wt. of water content for both systems. The low conductivity for water content $<50 \%$ wt. represented the limited movement and weak interaction of aqueous phase as water droplets were dispersed in the oil continuous phase due to the formation of water-in-oil (w/o) microemulsion (Cho et al. 2008). Moreover, the drastic increase in conductivity value starting at $50 \% \mathrm{wt}$. of water content was due to the strong interaction between the water droplets and the formation of interconductive channel which represented the formation of bicontinuous microemulsion. There was no formation of oil-in-water $(\mathrm{o} / \mathrm{w})$ microemulsion observed in this research. Generally, normal microemulsion systems show a percolation conductivity profile where it starts to increase slowly as the water content increases, then 


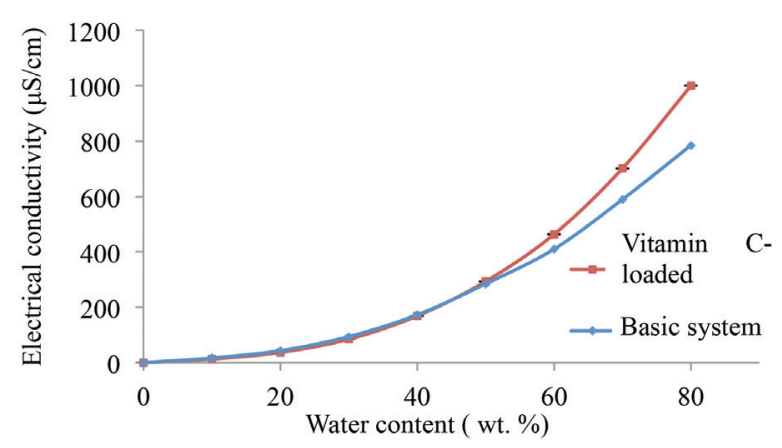

FIGURE 6. Electrical conductivity of basic and system with an addition of vitamin $\mathrm{C}$

increases drastically at a critical water level and remains constant with further addition of water content.

\section{CONCLUSION}

The effect of HLB value of the mixture of S/CoS on the formation of limonene-based microemulsion were studied. The HLB value calculated for the mixture of tween20/ propylene glycol was in a range between 10.1 and 13.4. The preparation of microemulsion system with tween 20 as surfactant and propylene glycol as co-surfactant were able to provide the large microemulsion region on ternary phase diagram $(23.6 \%)$ and showed a high stability. The higher the HLB value resulted broader microemulsion region in ternary phase diagrams. The higher the HLB mixture of S/CoS might increase the emulsification ability to more effective packing in the oil/water interfacial layer and greater interfacial rigidity. The effect of the addition of vitamin $\mathrm{C}$ to the basic system was also examined. Both systems showed high stability toward storage temperature $\left(25\right.$ and $40^{\circ} \mathrm{C}$ ) up to a month. The basic systems resulted on microemulsion's average particle size and the addition of vitamin $\mathrm{C}$ increased the average particle size of the basic systems especially for the w/o microemulsion due to solubilization vitamin $\mathrm{C}$ in aqeuous phase. The electrical conductivity test showed the transition microemulsion type from w/o to bicontinuous at $40 \%$ wt. of water content. Summarizing, the physicochemical characterizations results showed the potential of tween20/ limonene/propylene glycol/water microemulsion as carrier of vitamin $\mathrm{C}$.

\section{ACKNOWLEDGEMENTS}

The authors are grateful to Universiti Kebangsaan Malaysia for the research grant of GGP-2017-087 and GUP-2018-058.

\section{REFERENCES}

Alexander, A., Dwivedi, S., Ajazuddin, Giri, T.K., Saraf, S., Saraf, S. \& Tripathi, D.K. 2012. Approaches for breaking the barriers of drug permeation through transdermal drug delivery. Journal of Controlled Release 164(1): 26-40.

Bachysky, M.O., Shah, N.H., Patel, C.I. \& Malick, A.W. 1997. Factors affecting the efficiency of a self-emulsifying oral delivery system. Drug Development and Industrial Pharmacy 23(8): 809-816.

Basit, A., Newton, J. \& Lacey, L. 1998. The effect of polyethylene glycol 400(Peg 400) on gastrointestinal transit. Journal of Pharmacy and Pharmacology 50(S9): 97-97.

Chen, H., Chang, X., Weng, T., Zhao, X., Gao, Z., Yang, Y., Xu, H. \& Yang, X. 2004. A study of microemulsion systems for transdermal delivery of triptolide. Journal of Controlled Release 98(3): 427-436.

Cho, Y.H., Kim, S., Bae, E.K., Mok, C. \& Park, J. 2008. Formulation of a cosurfactant-free $\mathrm{o} / \mathrm{w}$ microemulsion using nonionic surfactant mixtures. Journal of Food Science 73(3): 115-121.

Chin, H.J. 2013. Mikroemulsi berasaskan minyak sawit bagi aplikasi losyen muka. Ijazah Sarjana Muda, Sains dan Teknologi, Universiti Kebangsaan Malaysia (Unpublished).

Cui, J., Yu, B., Zhao, Y., Zhu, W., Li, H., Lou, H. \& Zhai, G. 2009. Enhancement of oral absorption of curcumin by self-microemulsifying drug delivery systems. International Journal of Pharmaceutics 371(1): 148-155.

Fanun, M. 2010. Properties of microemulsions with mixed nonionic surfactants and citrus oil. Colloids and Surfaces A: Physicochemical and Engineering Aspects 369(1): 246-252.

Gadhave, A.D. \& Waghmare, J.T. 2014. A short review on microemulsion and its application in extraction of vegetable oil. International Journal of Research in Engineering and Technology 3(9): 147-158.

Gao, Z.G., Choi, H.G., Shin, H.J., Park, K.M., Lim, S.J., Hwang, K.J. \& Kim, C.K. 1998. Physicochemical characterization and evaluation of a microemulsion system for oral delivery of cyclosporin A. International Journal of Pharmaceutics 161(1): 75-86.

Hathout, R.M., Woodman, T.J., Mansour, S., Mortada, N.D., Geneidi, A.S. \& Guy, R.H. 2010. Microemulsion formulations for the transdermal delivery of testosterone. European Journal of Pharmaceutical Sciences 40(3): 188-196.

Herrera, J.R., Peralta, R.D., Lopez, R.G., Cesteros, L.C., Mendizabal, E. \& Puig, J.E. 2003. Cosurfactant effects on the polymerization of vinyl acetate in anionic microemulsion media. Polymer 44(6): 1795-1802.

Ismail, A.R., Wan Nurul Fatihah, W.Y., Daik, R. \& Hazimah, A.H. 2014. Effect of glycerol derived co-surfactant on the ternary phase behavior of palm-based microemulsions. Journal of Oil Palm Research 26(3): 240-250.

Jadhav, J.K. \& Sreenivas, S.A. 2012. Review on chemicals permeation enhancer used in transdermal drug delivery system. International Journal of Science Innovations and Discoveries 2(6): 204-217.

Khalid, N.R., Che Wel, C.A., Alam, S.S. \& Mokhtaruddin, S.A. 2018. Cosmetic for modern consumer: The impact of selfcongruity on purchase intention. International Journal of Asian Social Science 8(1): 34-41.

Kale, S.N. \& Deore, S.L. 2017. Emulsion, micro emulsion and nano emulsion: A review. Systematic Reviews in Pharmacy 8(1): 39-47.

Kogan, A., Aserin, A. \& Garti, N. 2007. Improved solubilization of carbamazepine and structural transitions in nonionic microemulsions upon aqueous phase dilution. Journal of Colloid and Interface Science 315(2): 637-647.

Lawrence, M.J. \& Rees, G.D. 2000. Microemulsion-based media as novel drug delivery systems. Advanced Drug Delivery Reviews 45(1): 89-121. 
Liu, C.H., Chang, F.Y. \& Hung, D.K. 2011. Terpene microemulsions for transdermal curcumin delivery: Effects of terpenes and cosurfactants. Colloids and Surfaces B: Biointrefaces 82: 63-70.

Lopes, L.B. 2014. Overcoming the cutaneous barrier with microemulsions. Pharmaceutics 6(1): 52-77.

Matsaridou, I., Barmpalexis, P., Salis, A. \& Nikolakakis, I. 2012. The influence of surfactant HLB and oil/surfactant ratio on the formation and properties of self-emulsifying pellets and microemulsion reconstitution. AAPS PharmaSciTech 13(4): 1319-1330.

Mohd Nadzir, M., Fen, T.W., Mohamed, A.R. \& Hisham, S.F. 2017. Size and stability of curcumin niosome from combinations of tween 80 and span 80. Sains Malaysiana 46(12): 2455-2460.

Matsaridou, I., Barmpalexis, P., Salis, A. \& Nikolakakis, I. 2012. The influence of surfactant HLB and oil/surfactant on the formation and properties of self-emulsifying pellets and microemulsion reconstitution. AAPS PharmaSciTech 13(4): 1319-1330.

Ozturk, B., Argin, S., Ozilgen, M. \& Mcclements, D.J. 2015. Formation and stabilization of nanoemulsion-based vitamin E delivery systems using natural biopolymers: Whey protein isolate and gum arabic. Food Chemistry 188(1): 256-263.

Pouton, C.W. 1985. Self-emulsifying drug delivery systems: Assessment of the efficiency of emulsification. International Journal of Pharmaceutics 27(2-3): 335-348.

Prausnitz, M.R. \& Langer, R. 2008. Transdermal drug delivery. Nature Biotechnology 26(11): 1261-1268.

Ramli, S., Norhman, N., Zainuddin, N., Mohd Ja'afar, S. \& Abdul Rahman, I. 2017. Nanoemulsion based palm olein as Vitamin E carrier. Malaysian Journal of Analytical Sciences 21(6): 1399-1408.

Ramli, S., Mohd Ja'afar, S., Abdul Sisak, M.A., Zainuddin, N. \& Abdul Rahman, I. 2015. Formulation and physical characterization of microemulsion based carboxymethyl cellulose as vitamin C carrier. Malaysian Journal of Analytical Sciences 19(1): 275-283.

Ramli, S., Ross, B.P. \& Gentle, I.R. 2009. Formulation and physical characterization of microemulsions containing isotretinoin. International Conference on Biomedical and Pharmaceutical Engineering. pp. 1-7.

Rehman, K. \& Zulfakar, M.H. 2014. Recent advances in gel technologies for topical and transdermal drug delivery. Drug Development and Industrial Pharmacy 40(4): 433-440.

Rehman, K., Mohd Amin, M.C. \& Zulfakar, M.H. 2014. Development and physical characterization of polymer-fish oil bigel (hydrogel/oleogel) system as a transdermal drug delivery vehicle. Journal of Oleo Science 63(10): 961-970.
Rozman, B., Zvonar, A., Falson, F. \& Gasperlin, M. 2009. Temperature-sensitive microemulsion gel: An effective topical delivery system for simultaneous delivery of Vitamins C and E. AAPS PharmSciTech 10(1): 54-61.

Sail, M.A., Wan Mustafa, W.A., Mohamad, Y.S., Maskat, M.Y. \& Shamsuddin, A.F. 2018. Optimisation of cinnamaldehydein-water nanoemulsion formulation using central composite rotatable design. Sains Malaysiana 47(9): 1999-2008.

Shah, V.P., Behl, C.R., Flynn, G.L., Higuchi, W.I. \& Schaefer, H. 1992. Principles and criteria in the development and optimization of topical therapeutic products. International Journal of Pharmaceutics 82: 21-28.

Shaninuzzaman, M., Yaakob, Z. \& Moniruzzaman, M. 2016. Medicinal and cosmetics soap production from Jatropha oil. Journal of Cosmetic Dermatology 15(2): 185-193.

Zainuddin, N., Ahmad, I., Abdul Rahman, I. \& Ramli, S. 2017. Kesan penambahan limonene terhadap mikroemulsi asid oleic/cremophor Rh 40/transcutol/air. Sains Malaysiana 46(10): 1797-1805.

Ramli, S.*, Chyi, K.T., Zainuddin, N. \& Mokhtar, W.N.A.W. Centre for Advanced Materials and Renewable Resources Faculty of Science and Technology

Universiti Kebangsaan Malaysia 43600 UKM Bangi, Selangor Darul Ehsan Malaysia

Ramli, S.*

Polymer Research Center

Faculty of Science and Technology

Universiti Kebangsaan Malaysia

43600 UKM Bangi, Selangor Darul Ehsan

Malaysia

Abdul Rahman, I.

Nuclear Technology Research Center

Faculty of Science and Technology

Universiti Kebangsaan Malaysia

43600 UKM Bangi, Selangor Darul Ehsan

Malaysia

*Corresponding author; email: su_ramli@ukm.edu.my

Received: 5 December 2018

Accepted: 19 March 2019 